The author's ambiguity also translates in other ways; indeed whether through indecisiveness or concern for impartiality Farley lets some doubts persist that lead to vague interpretations and sometimes give the impres-

sion of a dreamy, impractical man with wooly ideas on Being outside the club was an advantage.

ters in public health, but he knew how to surround himself with the best experts of the time and had confidence in youth. His directors of finance and publications were both aged 38 when appointed, and I recall when he officiated at our medical graduation, his passionate message was: "safeguard your such issues as poverty, family planning, peace, social services and medical coverage. That opponents during the Cold War might have thought this and used it against him may be understandable, but that another Canadian author should even today think that Chisholm was "a bit of a second rater" and that there was "mieux" (his italics) is untenable. ${ }^{1}$ Yes, like most people, Chisholm had his weaknesses and idiosyncrasies and he did not hold a mas- youthful vision and work health into social justice." And as his objective was the public's health rather than traditional public health, his being from outside the club should be seen as an advantage, as indeed it proved to be.

A postscript to the book would also have shown how much his visionary ideas have turned out to be not that illusory after all; to take just 1 example, the relationship between poverty and health, for which he was "crucified" by some at the time.

As an international organization, $\mathrm{WHO}$, even in the earliest years suffered from its members' nationalistic interests and lack of political will, exacerbated by the Cold War. The hot tensions were not particular to Chisholm's period - 4 of his successors faced similar problems — but it was he who first confronted them and, given the maddening complexities, it is to the credit of his capacity for damage control that the ship maintained its course and has safely sailed through its 60th year.

\section{S. William A. Gunn MD \\ Retired surgeon \\ Bogis-Bossey, Switzerland}

\section{REFERENCE}

1. Bliss M. "W.H.O. is Brock Chisholm?" Literary Review of Canada June 2008: 28-9.

\title{
Health as a bridge to peace
}

\section{Peace through Health: How Health Professionals Can Work for a Less Violent World \\ Neil Arya and Joanna Santa Barbara Kumarian Press; 2008. 341 pp \$39.95}

$\mathrm{P}$ eace through Health is a significant book that expresses and establishes the role of medical practitioners in the promotion of peace through their services in health, what WHO calls health as a bridge to peace.

Far from sounding like an idealistic slogan or impractical wishful thinking, the book's 27 chapters, written by 30 experienced researchers, practitioners or teachers with field exposure to the multifaceted aspects of health, disease and trauma in conflict and war (read peace-lacking) situations, describe the fundamentals of understanding, diagnosing and preventing, as well as possit ble therapies in the promotion of health as a contributor to peace.

We traditionally define and talk about war using the language of politics, a borrowed language in which we are not particularly adept. But what happens when a conflict is seen

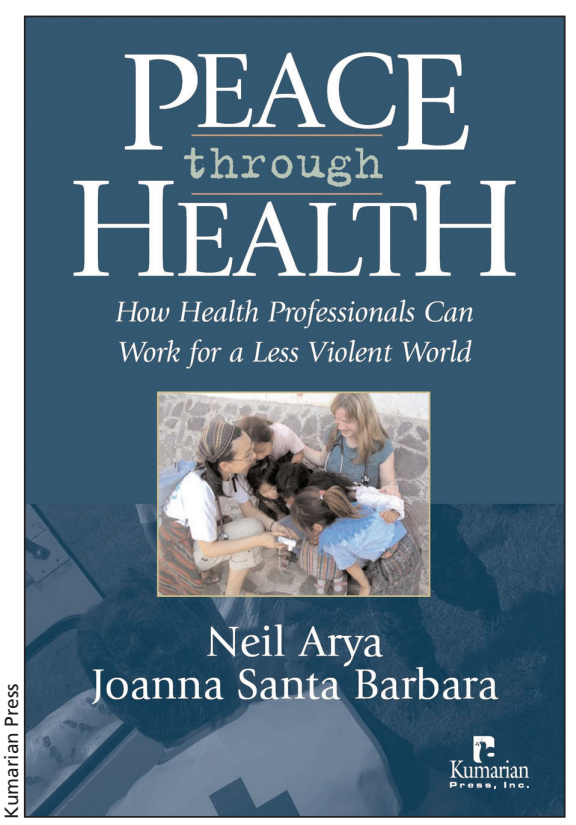

through the doctor's perspective? As distinct from politicians, can health professionals participate in mediation, mitigation and prevention of conflicts, and therefore promote peace? The book's answer is Yes.

As early as 1948 the Constitution of WHO stated that "the health of all peo- ples is fundamental to the attainment of peace and security." And as the authors amply demonstrate, the converse is true: health is strengthened through peace. Indeed the 1986 Ottawa Charter of WHO stresses that the fundamental conditions and resources for health are (in this order) peace, shelter, education, food, income, stable ecosystem, sustainable resources, social justice and equity. To the uninformed these may sound quite far from health or peace, but detailed case records make these assertions convincing and, indeed, invite for action. Readers will be proud that they belong to the profession that is committed to these humanist issues and can do something about them.

\section{S. William A. Gunn MD \\ Retired surgeon \\ Bogis-Bossey, Switzerland}

Dr. Gunn was a lecturer in History of Medicine and Science at the University of British Columbia in Vancouver before joining the World Health Organization. He is the founding president of the International Association for Humanitarian Medicine. 